Current perspectives on pedagogy for English as a lingua franca : [Review of Current perspectives on pedagogy for English as a lingua franca by Bayyurt \& Ackan]

\author{
Hynninen, Niina
}

2017

Hynninen, N 2017 , ' Current perspectives on pedagogy for English as a lingua franca : [Review of Current perspectives on pedagogy for English as a lingua franca by Bayyurt \& Ackan] ' , ELT Journal , vol. 71 , no. 2 , pp. 258-260 . https://doi.org/10.1093/elt/ccx001

http://hdl.handle.net/10138/230256

https://doi.org/10.1093/elt/ccx001

acceptedVersion

Downloaded from Helda, University of Helsinki institutional repository.

This is an electronic reprint of the original article.

This reprint may differ from the original in pagination and typographic detail.

Please cite the original version. 
Final draft of a review published in the ELT Journal:

Hynninen, Niina (2017) Current perspectives on pedagogy for English as a lingua franca. [Review of Current perspectives on pedagogy for English as a lingua franca, ed. by Jasemin Bayyurt and Sumru Akcan]. English Language Teaching Journal, 71 (2), 258-260. https://doi.org/10.1093/elt/ccx001.

\title{
Review
}

\section{Current Perspectives on Pedagogy for English as a Lingua Franca}

\author{
Y. Bayyurt and S. Akcan (eds.)
}

De Gruyter Mouton 2015, 260 pp., £82.99 (hardback)

ISBN 9783110322972

Research on English as a lingua franca (ELF) has both stirred enthusiasm and raised concern in language teaching circles. From its early days in the late 1990s to date, questions have been raised about how exactly to apply ELF research to pedagogy, but answers have been few and far between. The problem is that there are no simple answers. ELF researchers are at times criticized for merely describing how English is used in lingua franca settings, but descriptive research is needed to make pedagogical suggestions that build on actual ELF use. Much of ELF research has also focused on people's attitudes, but this, too, is important in order to see how receptive people would be for pedagogical practices drawing on ELF research. It takes time to develop viable pedagogical solutions.

Bayyurt and Akcan's edited collection of essays is a welcome contribution to pedagogical discussions around ELF. It aims to explicate the ways ELF research can contribute to practices of teaching and assessing English in different contexts, and importantly, some of the contributions in the volume provide readers with much-sought-after tangible solutions to the challenges of teaching and assessing English in the world today.

The book includes a short introductory chapter outlining the aims of the collection, and is then divided into four sections: 'Teaching and learning', 'Teacher education', 'Assessment', and 'Teaching materials'. Below, I take a look at common themes that characterize the different sections, highlighting any concrete solutions suggested in the chapters to incorporating an ELF perspective in practice. 
The first section, 'Teaching and learning', includes four quite different chapters. Flowerdew discusses the ELF and ESP interface. She highlights the importance of corpus research in sensitizing learners to the 'real' academic world, and with examples from her own teaching of grant proposal writing to engineering students in Hong Kong, she illustrates in what ways 'the writing of expert, multilingual writers in a particular academic genre could be put to good pedagogic use' (p. 17). This chapter is among the contributions that provide tangible solutions to incorporating ELF research findings in practice.

Another practical example is the second chapter by Hino and Oda, who introduce a teaching method developed and used at Osaka University in Japan, called IPTEIL or 'Integrated Practice in Teaching English as an International Language'. The chapter provides an example of how to prepare students for the diversity of voices, both in the sense of different Englishes and world views. This chapter is not simply a call for awareness-raising but an example of how students can actually be exposed to variety: IPTEIL can easily be modified to also take into account the specifics of ELF interaction.

The third chapter by Kohn is more conceptually oriented than the other chapters: it addresses the question of how ELF fits in with an overall Standard English orientation, which seems to prevail in English language teaching in secondary schools in Germany. Kohn suggests a shift from a 'strong' to a 'weak' Standard English orientation, which would mean seeing Standard English not as a target for the learners to be copied but as a direction for their learning activities. The main point is that the weak orientation leaves space for learners' own English to develop in ways that work in ELF communication, while still retaining Standard English as the target. What is important in this conceptualization is that it does not dismiss the continued influence of Standard English. However, at the same time it does not seem to take into account the possibility that once the 'my English[es]' (p. 55) of the individuals come into contact, they may develop into what could be termed 'our English', which may eventually influence the target that learners want to aspire to.

The last chapter in the first section, by Lopriore, talks about 'emerging features of ELF'. Her focus is on primary classrooms at European schools with high numbers of immigrant children contributing to the multiplicity of linguistic resources and to English often being used as a lingua franca both in and outside the classroom. The choice to focus on the English language classroom as a site for ELF was surprising, because there 
English is not only a possible lingua franca, but is also the learning target. However, the point made in the chapter about the increasing number of migrant children learning and also using ELF in the school context is highly valuable, and calls for further research. With its focus on ELF features, the chapter also highlights the communal or shared aspects of ELF.

As illustrated particularly by Chapters 3 and 4, the approaches to ELF in the book vary from talking about 'features of ELF' (Lopriore) to suggestions of teaching 'for ELF communication' rather than 'teaching ELF' (Kohn). The different approaches may be somewhat confusing particularly for a reader not used to ELF research, and the differences are not commented on by the editors. Importantly, such differences can shed light on different aspects of the ELF phenomenon. From a descriptive perspective, it is important to pay attention to 'features of ELF' that can shed light on language change in action, but from a pedagogical perspective, it seems more viable to teach 'for ELF communication' (as suggested by Kohn), emphasizing skills required to adapt to the changes.

The six chapters in Section 2 of the book provide suggestions of how to integrate ELF positions into teacher education programmes. Three of these contributions report on questionnaire studies among pre- or in-service teachers in three different countries, Portugal (Azuaga and Cavalheiro), Turkey (İnal and Özdemir), and Greece (Sougari and Faltzi). Azuaga and Cavalheiro's findings imply a tendency for teachers in Portugal to be influenced by NS models, which then prompts the authors to call for a reconsideration of the appropriateness of the NS model and English native language cultural content in English teaching, as well as for critical analysis of cultural content to increase intercultural awareness. İnal and Özdemir's findings show that awareness-raising of ELF increased the participants' favourable attitudes towards it. And Sougari and Faltzi conclude that, in their study, the participants with intercultural experience considered using English not only with NSs but also with NNSs of the language more likely than those who did not have such experience, but that such experience may not lead to more ELF-aware perceptions concerning the teaching of English in Greece. In general, these contributions are important in shedding light on the current situation of teacher education in different countries and in providing suggestions for further action.

Writing from within the context of the United Kingdom, both Blair and Dewey similarly call for changes in teacher education. Blair reports findings of a study of English 
teachers, all L2 users of English, who have received part of their teacher education in the United Kingdom. His contribution includes a list of proposals of how to integrate ELF positions in a teacher education programme. Dewey, furthermore, criticizes the most influential English language textbook publishers in the United Kingdom for being heavily biased towards British and American English, and for advertising themselves as preparing students for global communication even if the contents are native English speaker oriented. Based on recent findings from a study into professional beliefs of language teachers, he suggests refocusing teachers' concerns, and argues for an approach to language and communication that would be 'less concerned with language as an abstracted system and more in line with a notion of language as "local practice" (Pennycook 2010)' (p. 133).

The last contribution in the 'Teacher education' section, by Weber, criticizes the current foreign language assistant system in Austria, where nativeness is the only criterion required from an assistant. The problem is that in this system simply being a NS of a particular language may be valued more highly than language-pedagogical knowledge and experience. Weber suggests that in order to provide learners of English with a realistic reference point, schools would do well to hire multilingual assistants who have experience of using ELF and who are also interested in the teaching profession, rather than (monolingual) native English speakers simply for being NSs.

The two chapters in the 'Assessment' section introduce the Test of Oral English Proficiency for Academic Staff, or TOEPAS, developed and used at the University of Copenhagen, Denmark, to assess English language proficiency of lecturers (Chopin), and a prototype of an ELF-aware language test, called the Test of English for European University Students, or TEEUS, designed for university entrance, and developed in the Trinity College London, UK (Newbold). The latter chapter, by Newbold, provides an example of testing receptive skills, whereas the former chapter, by Chopin, suggests changing the test assessment criteria, which currently focus on grammatical correctness. Chopin argues that TOEPAS could be developed by changing the focus of the assessment to 'performance elements' (p. 200) that characterize accommodation, negotiation of meaning, and linguistic flexibility, motivated on the grounds that these are skills required by the test-takers in their everyday work. Chopin does not go into much detail about the 'performance elements', but previous descriptive research on academic ELF can be of use here (for example Mauranen 2012; Suviniitty 2012). 
The last two chapters of the book call for ELT materials to reflect the real world. Gimenez, Cabrini Simões Calvo, and Salles El Kadri analyse teaching materials produced by prospective English teachers in Brazil, and Sávio Pimentel Siqueira explores ELT textbooks, which like Dewey's analysis, were found to place heavy emphasis on English native language centres. Both of the contributions conclude that work is needed to translate ELF into the classroom.

In all, a common theme across the chapters is a call for real-world relevance in the teaching and assessment of English, which means not only incorporating an ELF perspective, but also doing that in locally meaningful ways. Particularly useful for English teachers and teacher educators are the examples of good practices and suggestions for further action, which the practitioners can use as a pool of ideas when developing their own teaching.

As we have seen, the contributions explore practices in various contexts and from different perspectives, covering several countries and education levels. A chapter on teaching English in the business context would have enriched the collection (see Pitzl and Ehrenreich 2015), and a commentary chapter would have been useful in drawing together the different contributions. When discussing pedagogical solutions to incorporating an ELF perspective, the individual contributions do not draw many links between the findings reported in the chapters and existing descriptive research on ELF. This is a pity since descriptive ELF research findings could have provided concrete examples of what to focus on in the teaching and assessment of English. A commentary would have therefore been a good opportunity to review ELF research findings more generally in the light of the pedagogical solutions suggested in the chapters.

In sum, this book is a useful reminder that there is no one solution to applying ELF research findings to pedagogy. Rather, it highlights the importance of finding solutions that work in particular contexts for particular learners, solutions that are based on ELFinformed decisions about why to teach English in a particular way.

\section{References}

Mauranen, A. 2012. Exploring ELF. Academic English Shaped by Non-native Speakers. Cambridge: Cambridge University Press.

Pennycook, A. 2010. Language as a Local Practice. London: Routledge. 
Pitzl, M-L. and S. Ehrenreich 2015. 'Teaching ELF, BELF, and/or intercultural communication? - an introduction'. Journal of English as a Lingua Franca (special issue) 4/1: 1-7.

Suviniitty, J. 2012. 'Lectures in English as a lingua franca: interactional features'. Unpublished $\mathrm{PhD}$ thesis, University of Helsinki, Finland. Available at http://urn.fi/URN:ISBN:978-95210-8540-6 (accessed on 30 November 2016).

\section{The reviewer}

Niina Hynninen is a postdoctoral researcher at the Department of Modern Languages, University of Helsinki, Finland. She has previously worked as a lecturer both at the University of Helsinki and at Stockholm University, Sweden. She has published on spoken academic ELF, with particular focus on language regulation, including a monograph with De Gruyter Mouton. Her current research focuses on the regulation of English-medium research writing.

\section{Email: niina.hynninen@helsinki.fi}

